\title{
Distribution and risk assessment of trace metals in riverine surface sediments in gold mining area
}

\author{
Jiangmin Song • Qunqun Liu • Yanqing Sheng
}

Received: 5 November 2018 / Accepted: 11 February 2019 /Published online: 27 February 2019

(C) Springer Nature Switzerland AG 2019

\begin{abstract}
Recognizing the pollution characteristics and potential risks of trace metals in sediments are important to protect water ecosystem safety. In the present study, a systematic investigation was performed to assess the pollution and risk level of trace metals in river sediments located in the greatest gold production base in China. The geo-accumulation index was used to assess the contamination degree. The sediment quality guidelines and potential ecological risk index were employed to complete an ecological risk assessment. A noncarcinogenic health risk assessment was also carried out to evaluate potential adverse health risks. Correlations and principal component analyses were applied to check relationships among trace metals and ascertain potential pollution sources. The results suggested that the sediments in the river were most polluted by As, $\mathrm{Cd}$, and $\mathrm{Hg}$ followed by $\mathrm{Cu}, \mathrm{Pb}$, and $\mathrm{Zn}$. The assessment of potential human health risk revealed that there was no significant non-carcinogenic risk to the inhabitants. Gold mining and smelting activities and the long-term
\end{abstract}

Electronic supplementary material The online version of this article (https://doi.org/10.1007/s10661-019-7311-9) contains supplementary material, which is available to authorized users.

J. Song $\cdot$ Q. Liu $\cdot$ Y. Sheng $(\bowtie)$

Research Center for Coastal Environment Engineering

Technology of Shandong Province, Yantai Institute of Coastal

Zone Research, Chinese Academy of Sciences, Yantai 264003,

China

e-mail: yqsheng@yic.ac.cn

J. Song · Q. Liu

University of Chinese Academy of Sciences, Beijing 100049,

China excessive application of fertilizers and agrochemicals were identified as the main anthropogenic releases. This study contributed an understanding that possible sources, contamination degree, and ecological risk level of trace metals in riverine surface sediments in a gold mining area.

Keywords Gold mining · Sediment · Trace metals · Assessment

\section{Introduction}

Trace metal contamination in aquatic system has attracted attention concerning their environmental endurance, biological accumulation, and potential adverse effects (Birch and Apostolatos 2013). In aquatic systems, trace metals quickly deposit into the sediment and then are combined with fine-grained components, iron and manganese oxides, organic matters, and sulfides (Tessier and Campbell 1987). Therefore, sediment was considered the main accumulation medium for trace metals (Pan and Wang 2012). However, metals combined in sediments may be released into the overlying water through the sediment-water interface, resulting in water quality deterioration and harmful effects on aquatic biota (Simpson and Batley 2007). Generally, anthropogenic metals have the characteristics of high mobility and toxicity to humans (Birch and Apostolatos 2013). Pan and Wang (2012) reported that a high metal content was observed in sediments along the coast resulting from industrial and domestic sewage discharges, 
mining, and smelting tailing, increasing the risk of metal exposure to biota. Previous study reported that a high freshwater content of $\mathrm{Hg}$ was dominantly produced by artisanal and small-scale gold mining (released to the environment at approximately $880 \mathrm{Mg}$ /year, Obrist et al. 2018). Therefore, understanding the distribution pattern and their potential ecological risks of trace metals in the gold mining area is significant to sediment quality evaluation and aquatic environment protection.

The Jiehe River is located in the biggest gold mining and smelting industrial zone in China. The local city (Zhaoyuan City) has been called the gold capital of China because it is situated in the Zhao-Lai gold mineralization belt and has the largest gold repository. In recent decades, many artisanal gold mines employed the rudimentary amalgamation method in the gold extraction process. In the rainy season, some tailing (fine-sand) is transported to the Jiehe River, resulting in trace metal pollution in sediments (Cai et al. 2016, 2017). Furthermore, acid mine drainage (AMD, $\mathrm{pH}<2$ ) is another unavoidable byproduct during gold production; it also contains a high concentration of dissolved trace metals. The untreated AMD discharge had a detrimental effect on aquatic plant and fish life (Feng et al. 2000). Therefore, the river water and sediments in the Jiehe River were likely simultaneously polluted by tailing and the drainage of AMD.

Prior to carrying out trace metal pollution remediation, it is necessary to ascertain the pollution characteristics and environmental risks in the sediments in the gold mining area. However, very few studies have examined contamination degree, evaluated environmental risks, or identified sources for trace metals in gold mining areas (Esdaile and Chalker 2018; Taiwo and Awomeso 2017). Thus, the present study aimed to (i) synchronously investigate the contents and distributions of $\mathrm{As}, \mathrm{Cd}, \mathrm{Cr}, \mathrm{Cu}, \mathrm{Pb}$, and $\mathrm{Zn}$ in surface sediments; (ii) ascertain the contamination condition and assess the ecological and health risk; and (iii) identify the potential origins of trace metals by correlation analysis and principal component analysis. These results can provide new knowledge for river ecosystem protection in gold mining area.

\section{Material and methods}

Study area

The Jiehe River (Fig. 1) is located in the northwestern Shandong Peninsula (E $120.08^{\circ}$ to $120.38^{\circ}$ and N $37.05^{\circ}$ to $37.33^{\circ}$ ). The area of the entire watershed is $\sim 585 \mathrm{~km}^{2}$, and the width is $70-120 \mathrm{~m}$. The sampling site was selected in the middle-lower reach with a dozen of gold mines and many gold smelting plants (e.g., the Jinling, Jinchiling, and Linglong gold mines) (Zhang et al. 2014). The continental climate of the study area is the continental monsoon type. The average annual temperature is $12.5^{\circ} \mathrm{C}$, and the mean annual rainfall is $669.2 \mathrm{~mm}$.

Sample collection and analysis

The top $0-5 \mathrm{~cm}$ of undisturbed surface sediment was collected using a Van-Veen grab sampler from 38 sites (J1-J38) in the Jiehe River (Fig. 1). These sites were distributed uniformly (an interval of $100 \mathrm{~m}$ ) across the middle-lower reaches (E $120.20^{\circ}$ to $120.32^{\circ}$ and $\mathrm{N}$ $37.21^{\circ}$ to $37.30^{\circ}$ ). Because of the narrow river, twopoints sediments $(2-3 \mathrm{~kg})$ were taken from each section and mixed them evenly to constitute the sediment sample of specific points. Samples were placed into polyethylene bags, stored in a cooler in the field, and stored at $4{ }^{\circ} \mathrm{C}$ in the laboratory before analysis.

The sediments were freeze-dried at $-50{ }^{\circ} \mathrm{C}$ and powdered with an agate mortar and pestle, and $\sim 4 \mathrm{~g}$ of powder was pressed to obtain powder pellets (Ahmadi et al. 2019). The trace elements were analyzed by $\mathrm{x}$-ray fluorescence (XRF) with the pressed power pellets, using an ARL AdvantXP automated X-ray spectrometer (Ruzickova et al. 2018). In this research, calibrations were performed with reference materials at each batch (30 samples determination), and matrix correction was obtained with the method of Lachance and Traill (1966) (Natali and Bianchini 2018). All analyses were carried out in duplicate. For trace elements at concentrations above $10 \mathrm{mg} / \mathrm{kg}$ in sediments, the errors were lower than $8 \%$ in the present study. To assure the reliability of analyses results, the intercalibration was covered in the applied XRF system on the sediment analysis that confirmed the precision and accuracy of the results (Vianello et al. 2014). Seven metals (Cd, Cr, Pb, $\mathrm{Hg}, \mathrm{As}, \mathrm{Cu}$, and $\mathrm{Zn}$ ) were determined for each sediment sample.

Contamination assessment methods

In this study, the geo-accumulation index $\left(I_{\text {geo }}\right)$ was applied to certify the geochemical figures of the 
Fig. 1 a Geographical position of the Jiaodong Peninsula elucidates the sitting of Jiehe River aera (black box). $\mathbf{b}$ The showing of Jiehe River basin. $\mathbf{c}$ The distribution of sampling sits (red cycles)

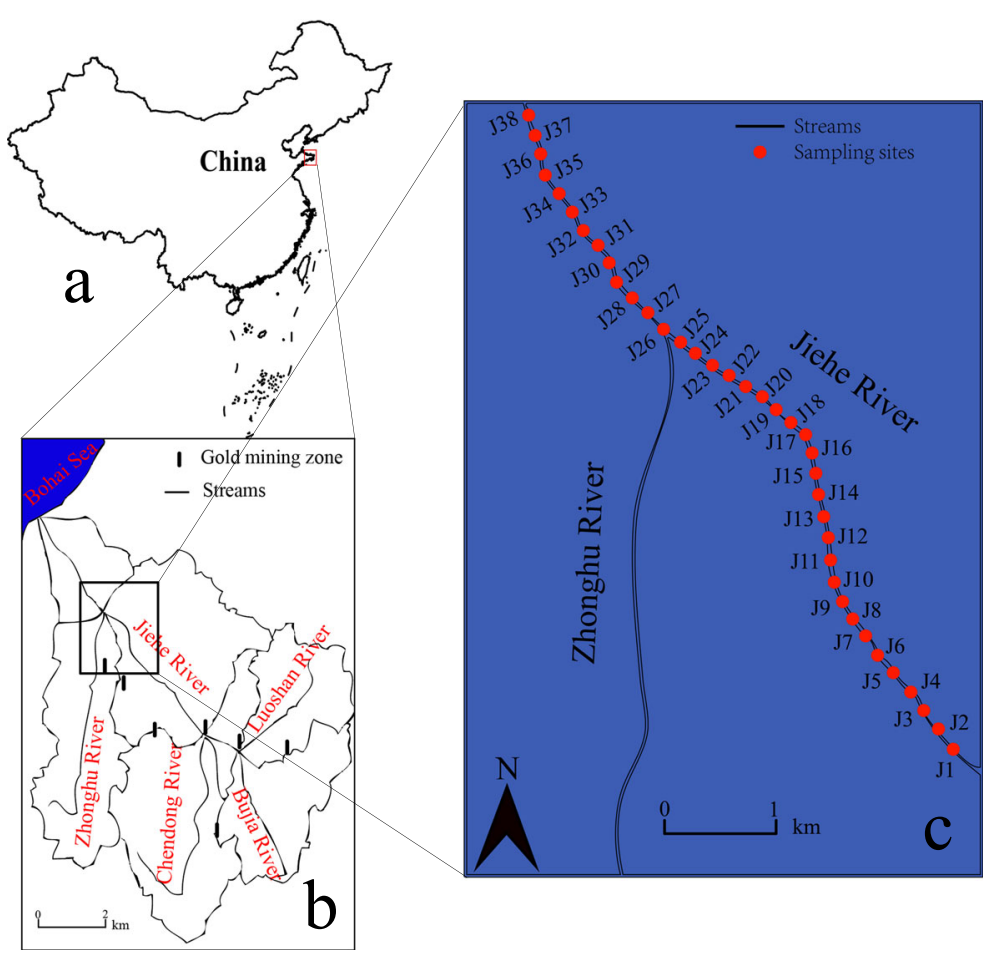

sediment metals. According to Muller (1969), $I_{\text {geo }}$ is used to identify metal accumulation in sediments and is calculated as defined below:

$I_{\text {geo }}=\log _{2}\left(C_{n} / 1.5 \times B_{n}\right)$

where $C_{n}$ is the determined content of each trace metal $(\mathrm{mg} / \mathrm{kg})$, and $B_{n}$ is defined as the geochemical background value of the corresponding trace metal $(\mathrm{mg} / \mathrm{kg})$. In the present study, the freshwater sediment background values in China were applied as the background value of trace metals in the studied area (Shi 2016). The coefficient of 1.5 was used to balance possible variations of the reference values resulting from the lithogenic effects. $I_{\text {geo }}$ consists of seven classes as described in Table 1.

\section{Ecological risk evaluation methods}

Sediment quality guidelines (SQGs) compared the sediment trace metal concentration to the corresponding specific quality criteria to qualitatively assess the probable environmental risk (Varol 2011). The SQGs were commonly produced from the previous freshwater sediment quality guidelines, and the method created by MacDonald et al. (2000) was applied to evaluate the grade of potential risks with the high concentration metals in sediments. There were two standards among the methods, including the threshold effect concentration (TEC) and the probable effect concentration (PEC). If the determined metals concentrations are below TEC, the adverse effects generated from trace metals are not expected to occur, and if the values are above PEC, harmful effects are expected to occur frequently. In addition, the mean PEC quotients (mPEC-Q) have been described using the following equation to assess the potential biotoxic effect for many metals (Long and Macdonald 1998a, b):

$\mathrm{mPEC}-\mathrm{Q}=\sum_{i=1}^{n} \frac{C_{i}}{\mathrm{PEC}_{i}} / n$

where $C_{i}$ is the content of each metal in the research, $\mathrm{PEC}_{i}$ is the corresponding PEC of each trace metal, and $n$ is the amount of determined metals in the research.

In addition, the potential ecological risk index (PERI), which indicates a toxic-response index for a particular metal, providing a definitive result for the potential risk with the pollution concentration 
Table 1 Summary of $I_{\text {geo }}$ classes, Er, and PERI risk levels

Contamination/risk grades

\begin{tabular}{llllll}
\hline$I_{\text {geo }}<0$ & Practically uncontaminated & Er $<40$ & Low risk & PERI $<100$ & Low risk \\
$0<I_{\text {geo }}<1$ & Uncontaminated to moderately contaminated & $40 \leq \mathrm{Er}<80$ & Moderate risk & $100 \leq$ PERI $<200$ & Moderate risk \\
$1<I_{\text {geo }}<2$ & Moderately contaminated & $80 \leq \mathrm{Er}<160$ & Considerable risk & $200 \leq$ PERI $<400$ & Considerable risk \\
$2<I_{\text {geo }}<3$ & Moderately to heavily contaminated & $160 \leq \mathrm{Er}<320$ & High risk & PERI $>400$ & Very high risk \\
$3<I_{\text {geo }}<4$ & Heavily contaminated & $\mathrm{Er} \geq 320$ & Very high risk & & \\
$4<I_{\text {geo }}<5$ & Heavily to extremely contaminated & & & \\
$I_{\text {geo }}>5$ & Extremely contaminated & & & \\
\hline
\end{tabular}

of metals to the ecological system (Hakanson 1980). The PERI revealed by the following formula includes the concentration and toxic-response indexes of trace metals and it can be applied to quantitatively assess the potential risks to ecosystem.

PERI $=\sum \operatorname{Er}^{i}=\sum T_{r}^{i} C_{f}^{i}=\sum T_{r}^{i}\left(C_{n}^{i} / C_{r}^{i}\right)$

where PERI is the total risk index for all metals in the research, Er is considered as the potential ecological risk value of a given metal, $T_{r}$ is the toxic-response index for a given metal, $C_{f}$ is considered as the pollution factor, $C_{n}$ is the contents of trace metal in the study $(\mathrm{mg} / \mathrm{kg})$, and $C_{r}$ is considered as the background value of a given metal $(\mathrm{mg} / \mathrm{kg})$. Consistent with Hakanson (1980), the consensus values $T_{r}$ of $\mathrm{Zn}, \mathrm{Cr}, \mathrm{Cu}, \mathrm{Pb}, \mathrm{As}, \mathrm{Cd}$, and $\mathrm{Hg}$ are $1,2,5,5,10,30$, and 40, respectively. Therefore, the assessment standards for Er of each metal are given for the five grades shown in Table 1. Hakanson indicated that seven metals ( $\mathrm{Cr}, \mathrm{As}, \mathrm{Cd}, \mathrm{Hg}, \mathrm{Pb}, \mathrm{Cu}$, and $\mathrm{Zn}$ ) and one organic pollutant (polychlorinated biphenyls, PCBs) were involved, but the PCBs were not been examined in this study. Therefore, the modified assessment standard of PERI for all metals (Liu et al. 2018b) was adopted. The detail criterias were listed in Table 1.

Health risk analysis method

A human health risk evaluation method applied for sediments has been presented in many studies (Iqbal et al. 2013; Khalil et al. 2015; Kusin et al. 2018). Commonly, the three major pathways of trace metals' transformation in ecological systems that are generally involved in human health risk assessment include the following: ingestion, dermal contact, and respiration. This study considered the ingestion and dermal contact pathways of sediment metals transportation to evaluate human health risk, and the following equations are used to calculate the exposure values (USEPA 1989, 2004; Rovira et al. 2011; Wang et al. 2005).

$\operatorname{Exp}_{\text {ing }}=\frac{C_{\text {sed }} \times \mathrm{IR} \times \mathrm{CF} \times \mathrm{EF} \times \mathrm{ED}}{\mathrm{BW} \times \mathrm{AT}}$

where $\operatorname{Exp}_{\text {ing }}$ is defined as the ingestion exposure risk from the sedimental metals $\left(\mathrm{mg} / \mathrm{kg} /\right.$ day); $C_{\text {sed }}$ is the determined content in present sediment; IR is defined as the amount of ingestion each day ( $\mathrm{IR}=114 \mathrm{mg} / \mathrm{day}$ ); $\mathrm{CF}$ is the measurement unit conversion factor $\left(\mathrm{CF}=10^{-6} \mathrm{~kg} / \mathrm{mg}\right.$ ); $\mathrm{EF}$ is defined as the exposure frequency on the sediment $(\mathrm{EF}=$ 350 days/year); $\mathrm{ED}$ is the exposure duration time ( $E D=30$ years); BW is defined as the adult weight $(\mathrm{BW}=70 \mathrm{~kg})$; $\mathrm{AT}$ is the number of days in 30 years ( $\mathrm{AT}=10,950$ days) (Iqbal et al. 2013).

$\operatorname{Exp}_{\text {derm }}=\frac{C_{\text {sed }} \times \mathrm{CF} \times \mathrm{SA} \times \mathrm{AF} \times \mathrm{ABS} \times \mathrm{EF} \times \mathrm{ED}}{\mathrm{BW} \times \mathrm{AT}}$

where $\operatorname{Exp}_{\text {derm }}$ is defined as the dermal uptake risk; SA is considered as the exposed skin area on the sediment $\left(\mathrm{SA}=5700 \mathrm{~cm}^{2}\right)$; AF is defined as the adhesion index of trace metal on unit skin area $\left(\mathrm{AF}=0.07 \mathrm{mg} / \mathrm{cm}^{2}\right)$; and $\mathrm{ABS}$ is considered as the dermal adsorption rate from sediment $(\mathrm{ABS}=$ 0.001) (Kusin et al. 2018), others were the same as above.

Hazardous quotients (HQs) were applied in evaluating the health risks of exposure to the trace metals of surface sediment in accordance with the USEPA (2004) health risk assessment guidelines (Wang et al. 2015). The HQs equation for the 
ingestion and dermal contact pathways are as follows:

$\mathrm{HQ}_{\text {ing } / \text { derm }}=\frac{\operatorname{Exp}_{\text {ing/derm }}}{\mathrm{RfD}}$

$\mathrm{HI}=\sum_{i=1}^{n} \mathrm{HQ}_{\text {ing } / \text { derm }}$

where HQ is the hazardous quotients by one exposure pathway of ingestion or dermal contact under respective exposure concentration; $\mathrm{RfD}$ is the reference value for the adverse health effort resulting from metal contaminations. The reference value through dermal contact is commonly regarded to be same as through the ingestion pathway (Iqbal et al. 2013).

Statistical analysis

Correlation and multivariate statistical tools including principal component analyses were applied to determine the strong relationships for trace metals in the sediment samples and ascertain the potential origins of sediment trace metals of Jiehe River. PCA is used to ascertain the sources of the trace metals by calculating the eigenvectors and identifying the principal components. In the PCA, varimax normalized rotation is applied and the principal components (PCs) can be identified on account of cumulative variance higher than $70 \%$ and/or an Eigenvalue greater than 1.0 (Varol 2011). The correlation and multivariable statistical analysis is performed using IBM SPSS 21 statistics software. The data analysis is given by Origin 9 statistics software for Windows.

\section{Results and discussion}

Trace metals distribution in sediments

Table 2 listed the summary of trace metal concentrations. The contents ranges $(\mathrm{mg} / \mathrm{kg})$ of $\mathrm{Cr} 12.5-78.8$, As 8.7-1674, Cd 0.1-394, Hg 5.2-51.0, Pb 18.3-426, Cu 8.1-1257, and Zn 53.6-1251. In order to estimate degree of contamination of trace metals in surface sediments, the sediment background values of freshwater lakes (SBVs) in China (Shi 2016), the average shale values of metals (ASVs) (Turekian 1961), and the Chinese environmental quality standard for soils (CEPA 1995) were applied. In Table 2 , the average contents of
$\mathrm{As}, \mathrm{Cd}, \mathrm{Cu}, \mathrm{Hg}, \mathrm{Pb}$, and $\mathrm{Zn}$ in the sediments were higher than the corresponding SBVs $(\mathrm{Hg}, \mathrm{Cd}, \mathrm{As}, \mathrm{Cu}, \mathrm{Zn}$, and $\mathrm{Pb}$, which were $622.2,329.8,16.5,10.3,10.3$, and 3.0 times the SBVs, respectively). Furthermore, the average content of each metal in the sediments exhibits metal distribution discrepancies compared to global the ASVs except for Cr. The results suggested that trace metals in sediments of the gold mining area were strongly affected by anthropogenic inputs (Ji et al. 2017).

In the CEPA (1995), the grade II level of quality standard for soils could be applied as the threshold values for protecting human health in China (Chen et al. 2016). Herein, approximately $100.0 \%$ of the samples for $\mathrm{Hg}, 86.8 \%$ for $\mathrm{Cd}, 78.9 \%$ for $\mathrm{As}, 63.1 \%$ for $\mathrm{Cu}$, and $39.5 \%$ for $\mathrm{Zn}$ exceeded their corresponding thresholds by comparison with the grade II level of quality standard. Compared with a previous study on the Jiehe River, the average $\mathrm{Cd}$ and As content in the present study are higher than the previous results by 2.3 and 8.8 times, respectively (Zhang et al. 2014). The increase or accumulation of $\mathrm{Cd}$ and As was likely related to the AMD discharge in the adjacent gold mines and smelting plants, as well as agrochemical overuse.

Spatially, the metal contents in sediments of the Jiehe River significantly varied between sampling points, with the following $\mathrm{CV}$ values: 0.52 of $\mathrm{Cr}, 2.06$ of As, 1.66 of $\mathrm{Cd}, 0.55$ of $\mathrm{Hg}, 1.15$ of $\mathrm{Pb}, 1.05$ of $\mathrm{Cu}$, and 0.83 of $\mathrm{Zn}$. The spatial distribution of $\mathrm{Cr}, \mathrm{As}, \mathrm{Cd}, \mathrm{Hg}, \mathrm{Pb}, \mathrm{Cu}$, and $\mathrm{Zn}$ in sediments is shown in Fig. 2.

The Cr concentration showed fluctuation in the studied area (Fig. 2a). The contents of $\mathrm{Cr}$ in most sample sites (30 of 38) were lower than the corresponding background reference values. The spatial distribution of $\mathrm{Cu}$ showed the following characteristics in concentration: the highest concentration appeared in the $\mathrm{J} 5$ site, and high concentrations presented in the $\mathrm{J} 26, \mathrm{~J} 30$, and J34 sites (Fig. 2b). The highest $\mathrm{Cu}$ concentration was 10.3 times higher than the reference value at the $\mathrm{J} 5$ site. The As and $\mathrm{Zn}$ concentrations in the surface sediment (Fig. 2b) were similar to $\mathrm{Cu}$, with high values at the $\mathrm{J} 5$, $\mathrm{J} 26, \mathrm{~J} 30$, and $\mathrm{J} 34$ sites. $\mathrm{Cd}, \mathrm{Hg}$, and $\mathrm{Pb}$ had generally common spatial concentration distribution (Fig. 2c). The highest content of $\mathrm{Cd}, \mathrm{Hg}$, and $\mathrm{Pb}$ at the $\mathrm{J} 9$ site were 394, 51.0, and $426 \mathrm{mg} / \mathrm{Kg}$, respectively (Table 2). However, except for J9 site, the concentration showed a narrow range.

The Jiehe River is located in the biggest gold mining and smelting industrial zones in China, so the river sediment could be contaminated with trace metals 
Table 2 Statistics of trace metals in sediment and various reference values (unit: $\mathrm{mg} / \mathrm{kg}$ )

\begin{tabular}{llllllll}
\hline & $\mathrm{Cr}$ & $\mathrm{As}$ & $\mathrm{Cd}$ & $\mathrm{Hg}$ & $\mathrm{Pb}$ & $\mathrm{Cu}$ & $\mathrm{Zn}$ \\
\hline Min & 12.5 & 8.70 & 0.09 & 5.2 & 18.3 & 8.1 & 53.6 \\
Mean & 35.8 & 131.9 & 36.3 & 16.8 & 65.8 & 206.0 & 297.6 \\
SD & 18.7 & 272 & 60.1 & 9.2 & 75.9 & 217.2 & 247.9 \\
Max & 78.8 & 1674 & 394 & 51.0 & 426 & 1257 & 1251 \\
CV & 0.52 & 2.06 & 1.66 & 0.55 & 1.15 & 1.05 & 0.83 \\
CEPA (grade II of soils) & 300 & 25 & 0.6 & 0.5 & 300 & 100 \\
SBVs & 54 & 8 & 0.11 & 0.027 & 22 & 20 & 250 \\
ASVs & 90 & 13 & 0.3 & 0.4 & 20 & 45 & 95 \\
\hline
\end{tabular}

produced by mine processing and smelting. A comparison of trace metals between the Jiehe River sediment and other rivers in gold mining areas and non-goldmining areas was listed in Table 3.

The comparison revealed that the content levels of $\mathrm{Cr}, \mathrm{As}, \mathrm{Cd}, \mathrm{Hg}, \mathrm{Pb}, \mathrm{Cu}$, and $\mathrm{Zn}$ are consistent with those in the Villa River (Ecuador) and the Certej River (Romania). For the metals in sediment without gold mining effects, the levels in this study were greater than those in the Ganga (India), Sungai Buloh (Malaysia), Jialu,
Yellow, and Yangtze (China) Rivers, with exception of Cr. The results indicated that the unavoidable byproducts in the mining industry may enhance the metal accumulation in riverine sediments.

Contamination assessment of metals in sediments

To identify the influence of human activities on trace metals' accumulation in surface sediment, the $I_{\text {geo }}$ was calculated (Fig. 3). The median $I_{\text {geo }}$ values for these

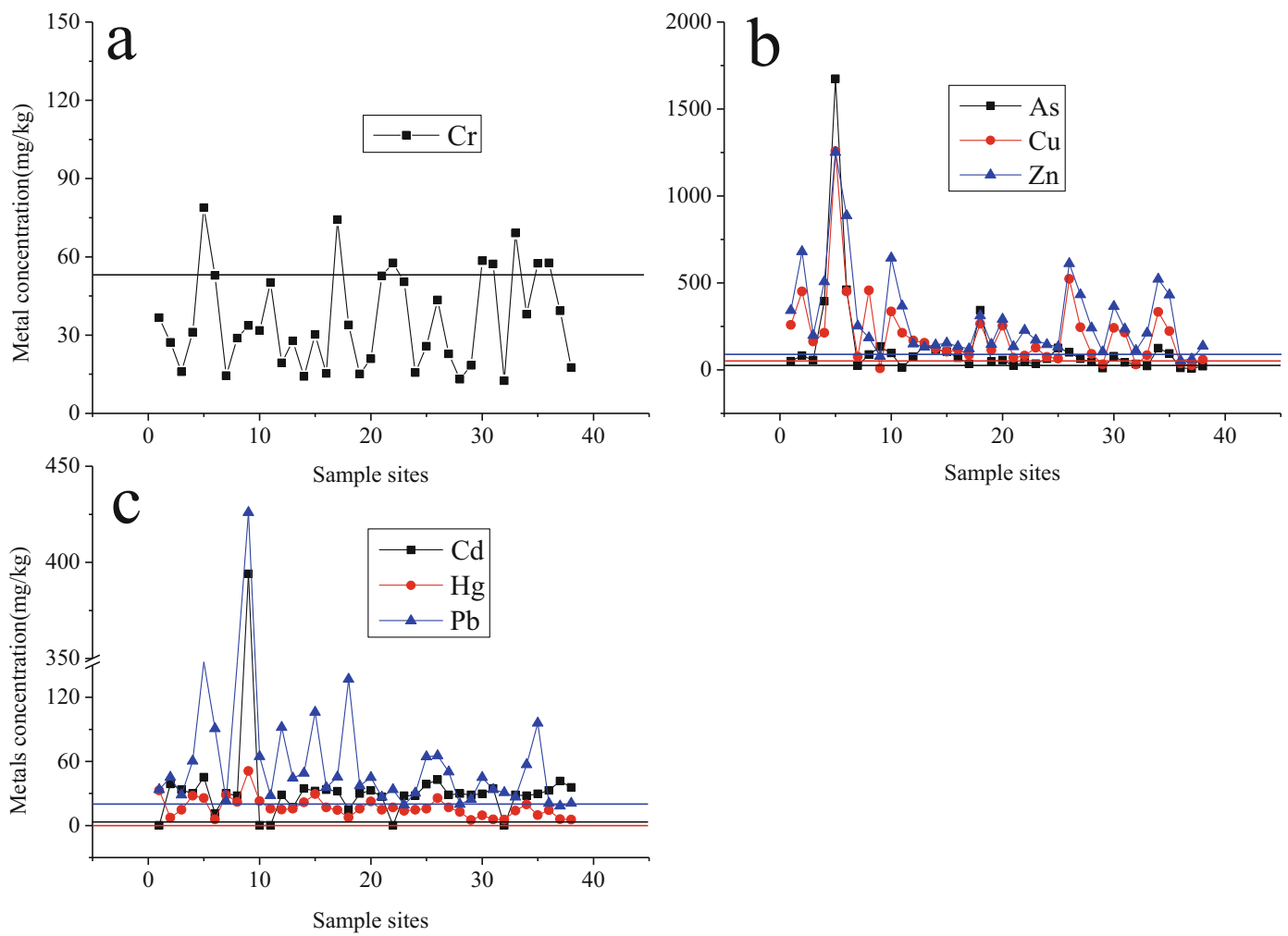

Fig. 2 Distribution of trace metals in sediments. (line: grade II level of the Chinese environmental quality standard for soils) 


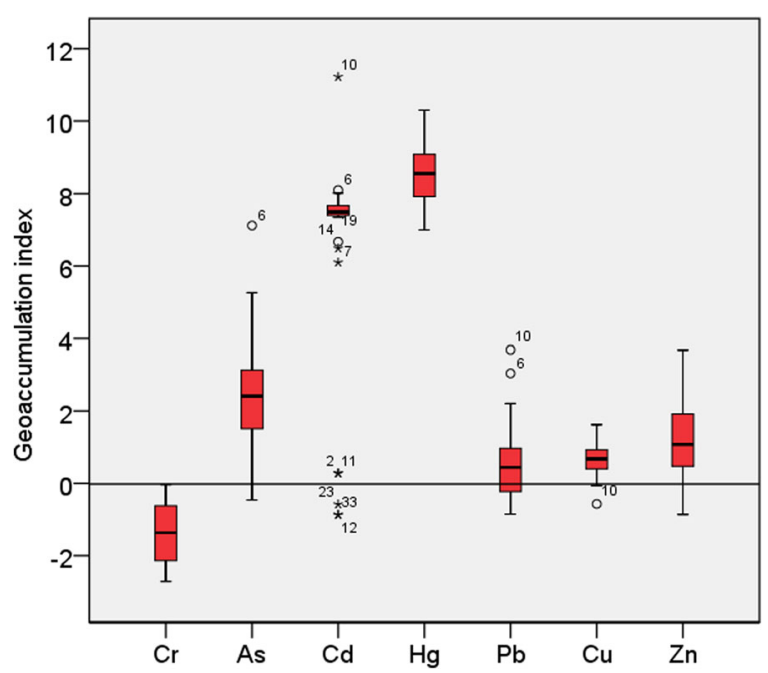

Fig. 3 Box-and-whisker plots for the $I_{\text {geo }}$ of trace metals in sediments

metals were different $(\mathrm{Hg}>\mathrm{Cd}>\mathrm{As}>\mathrm{Zn}>\mathrm{Cu}>\mathrm{Pb}>$ $\mathrm{Cr}$ ). The median $I_{\text {geo }}$ values for $\mathrm{Cd}$ and $\mathrm{Hg}$ were 7.49 and 8.56, respectively, presenting an extremely contaminated level. As and $\mathrm{Zn}$ led in moderately contaminated class, and $\mathrm{Pb}$ and $\mathrm{Cu}$ were the uncontaminated to moderately contaminated level. The highest mean $I_{\text {geo }}$ value was shown in $\mathrm{Cd}$ (7.49) and $\mathrm{Hg}$ (8.56) which were above class $6\left(I_{\text {geo }}>5\right)$, indicating the river was heavily polluted by $\mathrm{Cd}$ and $\mathrm{Hg}$. Previous studies revealed that the use of $\mathrm{Hg}$ in the amalgamation extraction process caused a large amount of AMD and waste effluents to be discharged to the Jiehe River from nearby gold mines or from large-scale mining and smelters/panning activities (Cai et al. 2017), resulting in the high accumulation of $\mathrm{Hg}$, As, and $\mathrm{Cd}$.

Ecological risks of trace metals in sediments

Based on the bioaccumulation and toxicity of trace metals on local biota, it is critical to evaluate the probable ecological risk of trace metals in sediment. Therefore, SQGs were applied to compare sediment contents of trace metals in contamination sediments with the corresponding standard values (Caeiro et al. 2005). The potential ecological risk index (PERI) of individual trace metal was evaluated to quantitatively assess their ecological risks.

Generally, SQGs can be widely applied to assess the sediment grade with contamination and contribute to understand sediment quality (Varol 2011). Table 4 listed the qualitative comparisons of trace metal concentrations 
Table 4 Percentages of sediment samples below TEC, between TEC and PEC, and above PEC in the Jiehe River

\begin{tabular}{lccccrrr}
\hline SQGs & $\mathrm{Cr}$ & $\mathrm{As}$ & $\mathrm{Cd}$ & $\mathrm{Hg}$ & $\mathrm{Pb}$ & $\mathrm{Cu}$ & $\mathrm{Zn}$ \\
\hline TEC & 43.40 & 9.79 & 0.99 & 0.18 & 35.80 & 31.60 & 121.0 \\
PEC & 111.0 & 33.00 & 4.98 & 1.06 & 128.0 & 149.0 & 459.0 \\
$<$ TEC $(\%)$ & 65.8 & 5.3 & 13.2 & 0.0 & 44.7 & 10.5 & 7.9 \\
TEC-PEC $(\%)$ & 34.2 & 15.8 & 0.0 & 0.0 & 44.7 & 39.5 & 73.7 \\
$>$ PEC $(\%)$ & 0.0 & 78.9 & 86.8 & 100.0 & 10.6 & 50.0 & 18.4 \\
\hline
\end{tabular}

in sediments with their consensus-based TEC and PEC values. The contents of $\mathrm{Hg}, \mathrm{Cd}, \mathrm{As}$, and $\mathrm{Cu}$ were higher than their corresponding PEC with $100.0 \%, 86.8 \%$, $78.9 \%$, and $50.0 \%$, respectively. These results indicated that all samples in the Jiehe River had $\mathrm{Hg}$ environmental risk and adverse effects on ecosystems. It also suggested that the majority of sites were affected by multiple trace metals (> 50\%). Approximately $34.2 \%$ for $\mathrm{Cr}, 44.7 \%$ for $\mathrm{Pb}, 39.5 \%$ for $\mathrm{Cu}$, and $73.7 \%$ for $\mathrm{Zn}$ were between the TEC and PEC values, indicating that $\mathrm{Cr}, \mathrm{Pb}$, and $\mathrm{Zn}$ may occasionally cause adverse effects on the environment, also implying $\mathrm{Cr}, \mathrm{Pb}$, and $\mathrm{Zn}$ have lower ecological risk than $\mathrm{Hg}$, As, $\mathrm{Cd}$, and $\mathrm{Cu}$.

For the toxic risk, mPEC-Q was calculated and illustrated in Fig. 4. According to the results of this method, sediment sites are predicted to not have toxicity if mPEC-Q $<0.1$; otherwise, sediment sites are considered to be toxic to ecological system (mPEC-Q > 1.0) (Long and Macdonald 1998a, b). In the present study, the calculated results of the MPEC-Q varied from 1.02 to 19.30 (Fig. 4). Therefore, all sediment samples were

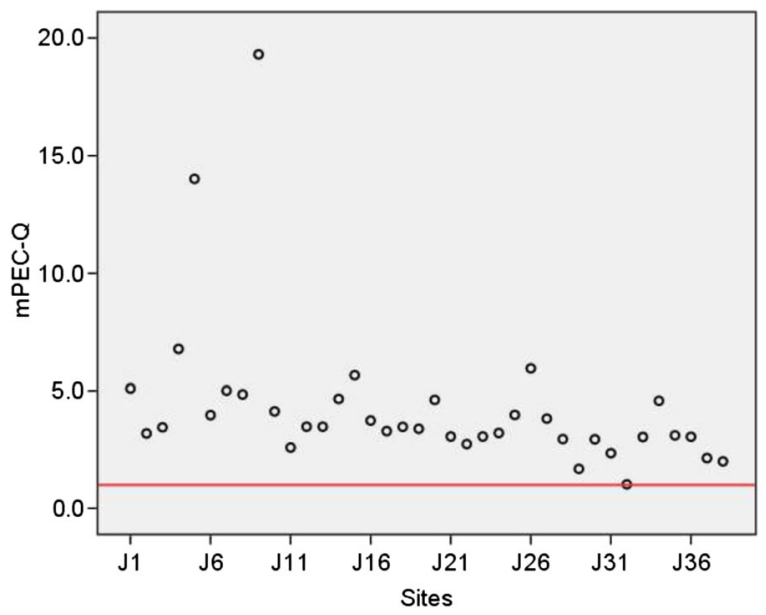

Fig. 4 The mPEC-Q of each sample site in Jiehe River (red line: $\mathrm{mPEC}-\mathrm{Q}=1$ ) toxic to sediment-welling organisms (mPEC-Q of $>$ 1.0). The result suggested that the combined trace metals' pollution is presented in Jiehe River sediments.

For ecological risk assessment, the PERI values of each sample sites ranged from 8380 to 183,276 with an average of 35,018 (Online Resource 1, Table S1). All sediment sample PERI values were much higher than 400, a high-risk criterion (Liu et al. 2018b), showing that a very high risk to the ecology was presented in Jiehe River sediments. The environmental risk of each metal in sediments was presented in Fig. 5. High concentrations or high toxic-response factor for single metals caused As, Cd, and $\mathrm{Hg}$ posed higher ecological risks than other metals. Particularly, the Er values for $100.0 \%$ of the $\mathrm{Hg}$ samples, $86.8 \%$ of $\mathrm{Cd}$, and $15.8 \%$ of As presented above high risks $(160 \leq \mathrm{Er}<320)$. Approximately $34.2 \% \mathrm{As}$, and $15.8 \% \mathrm{Cu}$ were at considerable risk $(80 \leq \mathrm{Er}<160)$. The highest Er values of As, $\mathrm{Cd}$, and $\mathrm{Hg}$ presented at the J6 (576.25), J9 (107,455), and J9 site $(75,556)$, respectively (Table S1). The high risk of As in the J6 site, in the vicinity of the agricultural land and rural areas, likely resulted from the abuse of

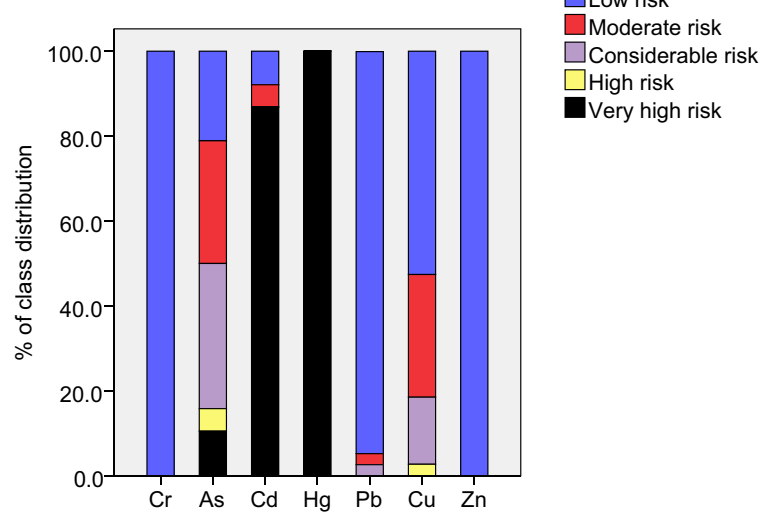

Fig. 5 Class distribution percentages for the ecological risk assessment of trace metals 
fertilizer, metal-containing pesticides, and herbicides in agriculture. The $\mathrm{Hg}$ high environmental risk at the J9 site may be seriously influenced by the near-by gold mining industries. Therefore, the potential risk decreased in the following order: $\mathrm{Hgs}>\mathrm{Cd}>\mathrm{As}>\mathrm{Cu}>$ $\mathrm{Pb}>\mathrm{Cr} / \mathrm{Zn}$. The results were in accordance with previous research, indicating that the sediment pollution of trace metals in the river occurred downstream as far as the adjacent area of the Bohai Sea (Li et al. 2018; Zhang et al. 2014).

In summary, nearly identical results were obtained by different assessment methods. The same result showed all sites in the Jiehe River were heavily polluted by multi-metals, and the pollution degree and ecological risks of $\mathrm{Hg}, \mathrm{Cd}, \mathrm{As}$, and $\mathrm{Cu}$ were much higher than those for $\mathrm{Cr}, \mathrm{Pb}$, and $\mathrm{Zn}$.

Health risk evaluation of trace metals

The HQs and HI values higher than 1 suggest adverse health effects from trace metals occurring in sediment. In the present study, HQs and HI values in sediments were less than 1 (Table 5), suggesting non-carcinogenic health risk was present, and the risks through two pathways of ingestion or dermal contact of trace metal were low. In Table 4, the HI value for ingestion of sediment is 0.889 . However, the HI value in the sediment is $3.11 \mathrm{E}-$ 03 through the dermal contact pathway. Therefore, the non-carcinogenic health risk for ingestion was greater than for dermal contact, suggesting that the ingestion pathway contributed more to the health risks of tracemetal-contaminated sediment. Additionally, the sequence of the $\mathrm{HQ}$ values of ingestion is $\mathrm{As}>\mathrm{Hg}>\mathrm{Cd}$ $>\mathrm{Pb}>\mathrm{Cr}>\mathrm{Cu}>\mathrm{Zn}$. The results revealed the major contribution of health risks by $\mathrm{As}, \mathrm{Hg}$, and $\mathrm{Cd}$ through ingestion and dermal contact, while $\mathrm{Cu}$ and $\mathrm{Zn}$ were the minor components for the non-carcinogenic risks to humans. The main contributions of $\mathrm{HI}$ are from As, $\mathrm{Hg}$, and $\mathrm{Cd}$, and $\mathrm{HQ}$ values of $\mathrm{As}, \mathrm{Hg}$, and $\mathrm{Cd}$ are $0.69,0.06$, and 0.09 , respectively. The HQ values remained contributed less to the HI value.

Source identification of trace metals in sediments

\section{Correlation analysis}

Correlations among trace metals in the studied area may represent the similar origin and transformation of these metals (Suresh et al. 2011). Metals revealing strong relationships may have common origins, similar migration behaviors with the changing physiochemical environment. If no relationship is found between two metals, the two metals will be not have many common factors (Kükrer et al. 2014). Positive correlations $(p<0.01)$ existed in the following metal pairs (Table 6): $\mathrm{As}-\mathrm{Pb}$ (0.520), As-Cu (0.835), As-Zn (0.744), Cu-Zn (0.889), $\mathrm{Cd}-\mathrm{Hg}$ (0.594), Cd-Pb (0.784), and Hg-Pb (0.607). Therefore, $\mathrm{As}, \mathrm{Cu}$, and $\mathrm{Zn}$ were found of a positive relationship among each other and might have common sources and transformation.

\section{PCA results}

PCA has been widely applied to further assist the source identification of trace metals in sediments (Jahan and Strezov 2018; Liu et al. 2018a; Xia et al. 2018). The meaning of Kaiser-Meyer-Olkin $(\mathrm{KMO}=0.673)$ and Bartlett's sphericity tests $(p=0)$ was that trace metal

Table 5 Description of health risk evaluation for trace metals in the sediment

\begin{tabular}{|c|c|c|c|c|c|}
\hline & \multirow[b]{2}{*}{$\mathrm{RfD}$} & \multicolumn{2}{|c|}{ Exposure assessment } & \multicolumn{2}{|c|}{ Non-carcinogenic risk } \\
\hline & & Exp $_{\text {ing }}$ & $\operatorname{Exp}_{\text {derm }}$ & $\mathrm{HQ}_{\text {ing }}$ & $\mathrm{HQ}_{\mathrm{derm}}$ \\
\hline $\mathrm{Cr}$ & $3.00 \mathrm{E}-03$ & 5.59E-05 & $1.96 \mathrm{E}-07$ & $1.86 \mathrm{E}-02$ & $6.52 \mathrm{E}-05$ \\
\hline As & $3.00 \mathrm{E}-04$ & $2.06 \mathrm{E}-04$ & 7.21E-07 & $6.87 \mathrm{E}-01$ & $2.40 \mathrm{E}-03$ \\
\hline $\mathrm{Cd}$ & $1.00 \mathrm{E}-03$ & $5.67 \mathrm{E}-05$ & $1.98 \mathrm{E}-07$ & $5.67 \mathrm{E}-02$ & $1.98 \mathrm{E}-04$ \\
\hline $\mathrm{Hg}$ & $3.00 \mathrm{E}-04$ & $2.62 \mathrm{E}-05$ & $9.18 \mathrm{E}-08$ & $8.75 \mathrm{E}-02$ & $3.06 \mathrm{E}-04$ \\
\hline $\mathrm{Pb}$ & $3.50 \mathrm{E}-03$ & $1.03 \mathrm{E}-04$ & $3.60 \mathrm{E}-07$ & $2.94 \mathrm{E}-02$ & $1.03 \mathrm{E}-04$ \\
\hline $\mathrm{Cu}$ & $4.00 \mathrm{E}-02$ & $3.22 \mathrm{E}-04$ & $1.13 \mathrm{E}-06$ & $8.04 \mathrm{E}-03$ & $2.81 \mathrm{E}-05$ \\
\hline $\mathrm{Zn}$ & $3.00 \mathrm{E}-01$ & $4.65 \mathrm{E}-04$ & $1.63 \mathrm{E}-06$ & $1.55 \mathrm{E}-03$ & $5.42 \mathrm{E}-06$ \\
\hline $\mathrm{HI}_{\text {ing/derm }}$ & & & & 8.89E-01 & $3.11 \mathrm{E}-03$ \\
\hline
\end{tabular}


Table 6 Pearson's correlation result of trace metals in the sediments

\begin{tabular}{lllllll}
\hline & $\mathrm{Cr}$ & $\mathrm{As}$ & $\mathrm{Cd}$ & $\mathrm{Hg}$ & $\mathrm{Cu}$ & $\mathrm{Zn}$ \\
$\mathrm{Cr}$ & & & & & \\
$\mathrm{As}$ & $0.361^{*}$ & & & & \\
$\mathrm{Cd}$ & -0.019 & 0.037 & 0.173 & $0.594^{* *}$ & & \\
$\mathrm{Hg}$ & -0.049 & $0.520^{* *}$ & $0.784^{* *}$ & $0.607^{* *}$ & & $0.389^{* *}$ \\
$\mathrm{~Pb}$ & 0.167 & $0.835^{* *}$ & -0.114 & 0.134 & 0.273 & $0.889^{* *}$ \\
$\mathrm{Cu}$ & $0.366^{*}$ & $0.744^{* *}$ & -0.142 & 0.081 & 0.273 \\
$\mathrm{Zn}$ & $0.364^{*}$ & & & & \\
\hline
\end{tabular}

* Significant at $p<0.05$ levels. ${ }^{* *}$ Significant at $p<0.01$ levels

concentrations in surface sediments in Jiehe River were suitable for PCA analysis.

Table 7 listed the results of PCA using a varimax rotation process for trace metals and Fig. 6 illustrated the variation diagram in a rotated space. The initial dimensions of 38 in the data reduce to three PCs by PCA which explain $87.91 \%$ of the data variation. PC 1 was heavily loaded with $\mathrm{Cu}, \mathrm{Zn}$, and As which explained $45.82 \%$ of the total variance and showed an eigenvalue of 3.207. PC 2 explained $30.51 \%$ and had a strong correlation with $\mathrm{Cd}(0.921), \mathrm{Pb}(0.886)$, and $\mathrm{Hg}$ (0.820). PC 3 explained $11.58 \%$ and was strongly relevant with $\mathrm{Cr}(0.954)$.

\section{Sources identification}

Three main sources could be certified by the previously mentioned correlation, PCA, and the spatial distribution

Table 7 PCA analysis result of trace metals in the sediments of the Jiehe River

\begin{tabular}{lccc}
\hline Metals & \multicolumn{3}{l}{ Rotated component matrix } \\
\cline { 2 - 4 } & PC 1 & PC 2 & PC 3 \\
\hline $\mathrm{As}$ & 0.883 & 0.201 & 0.171 \\
$\mathrm{Cu}$ & 0.961 & 0.054 & 0.127 \\
$\mathrm{Zn}$ & 0.928 & -0.024 & 0.130 \\
$\mathrm{Cd}$ & -0.182 & 0.929 & 0.075 \\
$\mathrm{Hg}$ & 0.114 & 0.813 & -0.168 \\
$\mathrm{~Pb}$ & 0.334 & 0.882 & 0.132 \\
$\mathrm{Cr}$ & 0.252 & -0.007 & 0.954 \\
Initial eigenvalues & 3.207 & 2.136 & 0.811 \\
$\%$ of variance & 45.82 & 30.51 & 11.58 \\
Cumulative \% & 45.82 & 76.33 & 87.91 \\
\hline
\end{tabular}

Italic data are the main contribution elements to factor analyses of trace metals in surface sediments, i.e., (1) $\mathrm{As}, \mathrm{Cu}$, and $\mathrm{Zn}$ mostly originated from agricultural sources; (2) $\mathrm{Cd}, \mathrm{Hg}$, and $\mathrm{Pb}$ directly originated from industrial and mining efforts; and (3) Cr mainly produced by natural sources.

Based on PC 1 analysis, As, $\mathrm{Zn}$, and $\mathrm{Cu}$ exhibit a high $\mathrm{CV}$ indicating anthropogenic activities were the primary source because the mean concentrations were higher than their ASVs and SBVs. The correlation analysis showed strong relativity among the $\mathrm{As}, \mathrm{Cu}$, and $\mathrm{Zn}$, with similar spatial distribution trends. Previous studies revealed that the trace metal was a threat to human life in agricultural areas due to the abuse of agricultural pesticides and chemical fertilizers (Kalaivanan and Ganeshamurthy 2016; Rai et al. 2016). The main human origin of $\mathrm{Cu}$ in agricultural soils was the application of $\mathrm{Cu}$-based agrochemicals and phosphate fertilizers (Micó et al. 2006). Inorganic As compounds were widely applied in insecticides, herbicides, and pesticides to

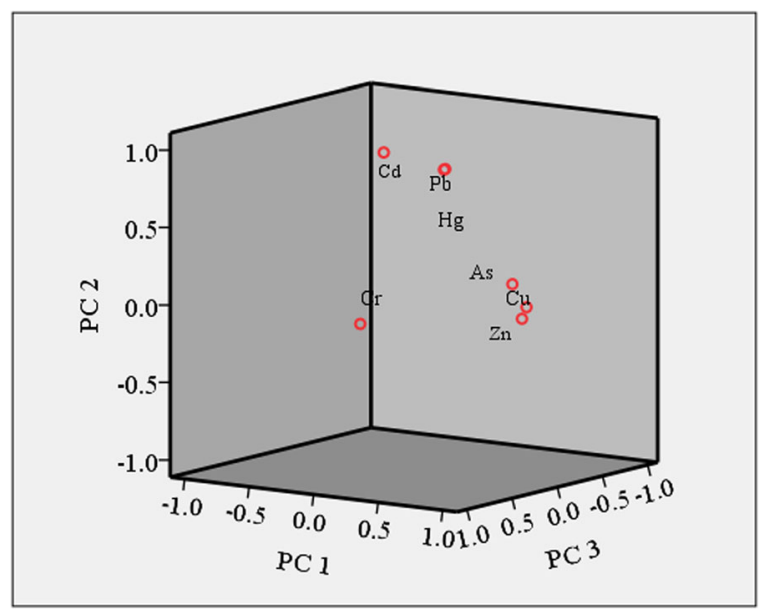

Fig. 6 Loading plot of the PCA of trace metals in the sediment of the Jiehe River 
improve insecticidal effort (Cai et al. 2015). Chen et al. (2018) also reported that the average total input amount of $\mathrm{Cu}$ and $\mathrm{Zn}$ annually $\left(\mathrm{mg} / \mathrm{m}^{2} / \mathrm{a}\right.$ ) from the agricultural fertilizer were 13.313 and 2.376 , respectively. There was a large scale wheat, maize, and vegetables in the study area, so the application of fertilizers and pesticides may be the primary source of $\mathrm{Cu}, \mathrm{Zn}$, and As. Thus, the first component can be defined as the agricultural component.

The PC2 consisted of $\mathrm{Cd}, \mathrm{Hg}$, and $\mathrm{Pb}$, which can be considered as the industrial component. The highest concentration of $\mathrm{Cd}, \mathrm{Hg}$, and $\mathrm{Pb}$ at the $\mathrm{J} 9$ site, which was near the gold production industry of the Jinchiling gold mine, indicating their main source was from mining and smelting industries. The $I_{\text {geo }}$ of $\mathrm{Cd}$ and $\mathrm{Hg}$ were above class 6 and were higher than their background values. High concentrations of $\mathrm{Hg}, \mathrm{Cd}$, and $\mathrm{Pb}$ were found in soils, sediments, and waters in the vicinity of mining activities (Marrugo-Negrete et al. 2017; MortonBermea et al. 2014; Strzebońska et al. 2017). Therefore, $\mathrm{Cd}, \mathrm{Hg}$, and $\mathrm{Pb}$ were possibly caused by anthropogenic inputs from upstream gold smelting industries in this study because small-scale gold mining often employs the immature amalgamation technique (Esdaile and Chalker 2018). Trace metals delivered by AMD, mining influent, and tailing were first transferred into water through sorption and precipitation processes, and then the metals were delivered to the sediments in the Jiehe River. Consequently, $\mathrm{Cd}, \mathrm{Hg}$, and $\mathrm{Pb}$ might mainly originate from mining and smelting activities.

For the PC 3, the $\mathrm{Cr}$ did not cause pollution. The concentration of $\mathrm{Cr}$ was slightly close to the ASVs. Furthermore, the $I_{\text {geo, }}$ SQGs, and Er results suggested that the contents of $\mathrm{Cr}$ revealed a low or zero potential ecological risk. These results indicated that $\mathrm{Cr}$ might produce from natural sources.

\section{Conclusion}

The river sediments were heavily contaminated with As, $\mathrm{Cd}$, and $\mathrm{Hg}$ with the developing mining technology and agricultural activity in past decades. The contents of trace metals showed heterogeneity in the spatial distribution. By assessing trace metals in sediment, the potential ecological risks of $\mathrm{Hg}, \mathrm{Cd}, \mathrm{As}$, and $\mathrm{Cu}$ in sediments were shown to be at high-risk levels and were harmful to sediment-dwelling organisms. The evaluation of possible human health risks suggested that low non-carcinogenic health risk existed for exposure to sediment via ingestion or dermal contact. Source identification revealed that trace metals in sediments mainly originated from gold mining discharges, industrial effluents, and agricultural activities.

Funding information This study was supported by the Strategic Priority Research Program of the Chinese Academy of Sciences (Grant No. XDA23050203) and the National Natural Science Foundation of China (Grant No. 41373100). Additional support was provided by the CAS Key Technology Talent Program and the Instrument Developing Project of the Chinese Academy of Sciences (Grant No. Y728021021).

Publisher's note Springer Nature remains neutral with regard to jurisdictional claims in published maps and institutional affiliations.

\section{References}

Ahmadi, P., Ghorbani, M. R., Coltorti, M., Kuritani, T., Cai, Y., Fioretti, A. M., Braschi, E., Giacomoni, P. P., Aghabazaz, F., Babazadeh, S., \& Conticelli, S. (2019). High-Nb hawaiitemugearite and high-Mg calc-alkaline lavas from northeastern Iran: Oligo-Miocene melts from modified mantle wedge. International Geology Review, 61, 150-174. https://doi. org/10.1080/00206814.2017.1416502.

Birch, G. F., \& Apostolatos, C. (2013). Use of sedimentary metals to predict metal concentrations in black mussel (Mytilus galloprovincialis) tissue and risk to human health (Sydney estuary, Australia). Environmental Science and Pollution Research, 20, 5481-5491. https://doi.org/10.1007/s11356013-1538-8.

Caeiro, S., Costa, M. H., Ramos, T. B., Fernandes, F., Silveira, N., Coimbra, A., Medeiros, G., \& Painho, M. (2005). Assessing heavy metal contamination in Sado Estuary sediment: an index analysis approach. Ecological Indicators, 5, 151-169. https://doi.org/10.1016/j.ecolind.2005.02.001.

Cai, L., Xu, Z., Bao, P., He, M., Dou, L., Chen, L., Zhou, Y., \& Zhu, Y. G. (2015). Multivariate and geostatistical analyses of the spatial distribution and source of arsenic and heavy metals in the agricultural soils in Shunde, Southeast China. Journal of Geochemical Exploration, 148, 189-195. https://doi.org/10.1016/j.gexplo.2014.09.010.

Cai, Y. B., Mi, Y. T., Yu, J., \& Zhang, H. (2016). Arsenic speciation and kinetic release simulation of stream sediment contaminated by gold mining. Journal of Soils and Sediments, 16, 1121-1129. https://doi.org/10.1007/s11368-015-1334-9.

Cai, Y. B., Zhang, H., Yuan, G. D., \& Li, F. Y. (2017). Sources, speciation and transformation of arsenic in the gold mining impacted Jiehe River, China. Applied Geochemistry, 84, 254-261. https://doi.org/10.1016/j.apgeochem.2017.07.001.

CEPA. (1995). Environmental quality standard for soils. (GB15618-1995), first edition. Beijing: Chinese Environmental Protection Administration.

Chen, H., Chen, R., Teng, Y., \& Wu, J. (2016). Contamination characteristics, ecological risk and source identification of 
trace metals in sediments of the Le'an River (China). Ecotoxicology and Environmental Safety, 125, 85-92. https://doi.org/10.1016/j.ecoenv.2015.11.042.

Chen, L., Zhou, S., Wu, S., Wang, C., Li, B., Li, Y., \& Wang, J. (2018). Combining emission inventory and isotope ratio analyses for quantitative source apportionment of heavy metals in agricultural soil. Chemosphere, 204, 140-147. https://doi.org/10.1016/j.chemosphere.2018.04.002.

Darwish, M. A. G. (2017). Reconnaissance geochemical survey in the Marahiq area, Wadi Allaqi region, south Egypt: a preliminary assessment of stream sediments for gold placer and environmental hazard. Environmental Earth Sciences, 76, 493-516. https://doi.org/10.1007/s12665-017-7152-1.

Esdaile, L. J., \& Chalker, J. M. (2018). The mercury problem in artisanal and small-scale gold mining. Chemistry-A Europen Journal, 24, 6905-6916. https://doi.org/10.1002 /chem.201704840.

Feng, D., Aldrich, C., \& Tan, H. (2000). Treatment of acid mine water by use of heavy metal precipitation and ion exchange. Minerals Engineering, 13, 623-642. https://doi.org/10.1016 /S0892-6875(00)00045-5.

Fu, J., Zhao, C., Luo, Y., Liu, C., Kyzas, G. Z., Luo, Y., Zhao, D., An, S., \& Zhu, H. (2014). Heavy metals in surface sediments of the Jialu River, China: Their relations to environmental factors. Journal of Hazardous Materials, 270, 102-109. https://doi.org/10.1010/j.jhazmat.2014.01.044.

Gao, Z. X. (2018). Evaluation of heavy metal pollution and its ecological risk in one river reach of a gold mine in Inner Mongolia, Northern China. International Biodeterioration, 128, 94-99. https://doi.org/10.1016/j.ibiod.2017.01.001.

Hakanson, L. (1980). An ecological risk index for aquatic pollution control.a sedimentological approach. Water Research, 14, 975-1001. https://doi.org/10.1016/0043-1354(80 90143-8.

Iqbal, J., Tirmizi, S. A., \& Shah, M. H. (2013). Statistical apportionment and risk assessment of selected metals in sediments from Rawal Lake (Pakistan). Environmental Monitoring and Assessment, 185, 729-743. https://doi.org/10.1007/s10661012-2588-y.

Jahan, S., \& Strezov, V. (2018). Comparison of pollution indices for the assessment of heavy metals in the sediments of seaports of NSW, Australia. Marine Pollution Bulletin, 128, 295-306. https://doi.org/10.1016/j.marpolbul.2018.01.036.

Ji, H., Li, H., Zhang, Y., Ding, H., Gao, Y., \& Xing, Y. (2017). Distribution and risk assessment of heavy metals in overlying water, porewater, and sediments of Yongding River in a coal mine brownfield. Journal of Soils and Sediments, 18, 624-639.

Kalaivanan, D., \& Ganeshamurthy, A. N. (2016). Abiotic stress physiology of horticultural crops. In Mechanisms of heavy metal toxicity in plants (1st ed., pp. 85-102). New Delhi: Springer India.

Khalil, M. K., Draz, S. E. O., El Zokm, G. M., \& El-Said, G. F. (2015). Apportionment of geochemistry, texture's properties, and risk assessment of some elements in surface sediments from Bardawil Lagoon, Egypt. Human and Ecological Risk Assessment: An International Journal, 22, 775-791. https://doi.org/10.1080/10807039.2015.1107714.

Kim, L., Vasile, G.G., Stanescu, B., Dinu, C., Ene, C. (2016). Distribution of Trace Metals in Surface Water and Streambed Sediments in the Vicinity of an Abandoned Gold Mine from Hunedoara County, Romania. Revista De Chimie, 67, 1441-1446.
Kükrer, S., Șeker, S., Abacı, Z. T., \& Kutlu, B. (2014). Ecological risk assessment of heavy metals in surface sediments of northern littoral zone of Lake Çıldır, Ardahan, Turkey. Environmental Monitoring and Assessment, 186, 38473857. https://doi.org/10.1007/s10661-014-3662-4.

Kusin, F. M., Azani, N. N. M., Hasan, S. N. M. S., \& Sulong, N. A. (2018). Distribution of heavy metals and metalloid in surface sediments of heavily-mined area for bauxite ore in Pengerang, Malaysia and associated risk assessment. Catena, 165, 454-464. https://doi.org/10.1016/j. catena.2018.02.029.

Lachance, G. R., \& Traill, R. J. (1966). Practical solution to the matrix problem in X-ray analysis, I. Method: Canadian. Spectroscopy, 11, 43-48.

Li, H., Gao, X., Gu, Y., Wang, R., Xie, P., Liang, M., Ming, H., \& $\mathrm{Su}$, J. (2018). Comprehensive large-scale investigation and assessment of trace metal in the coastal sediments of Bohai Sea. Marine Pollution Bulletin, 129, 126-134. https://doi. org/10.1016/j.marpolbul.2018.02.022.

Liu, H. Q., Liu, G. J., Wang, S. S., Zhou, C. C., Yuan, Z. J., \& Da, C. N. (2018a). Distribution of heavy metals, stable isotope ratios (delta C-13 and delta N-15) and risk assessment of fish from the Yellow River Estuary, China. Chemosphere, 208, 731-739. https://doi.org/10.1016/j.chemosphere.2018.06.028.

Liu, Q., Wang, F., Meng, F., Jiang, L., Li, G., \& Zhou, R. (2018b). Assessment of metal contamination in estuarine surface sediments from Dongying City, China: Use of a modified ecological risk index. Marine Pollution Bulletin, 126, 293-303. https://doi.org/10.1016/j.marpolbul.2017.11.017.

Liu, Y. F., et al. (2018c). Comprehensive risk assessment and source apportionment of heavy metal contamination in the surface sediment of the Yangtze River Anqing section, China. Environmental Earth Sciences, 77, 493-504. https://doi.org/10.1007/s12665-018-7621-1.

Long, E. R., \& Macdonald, D. D. (1998a). Recommended uses of empirically derived, sediment quality guidelines for marine and estuarine ecosystems. Human and Ecological Risk Assessment: An International Journal, 4, 1019-1039.

Long, E. R., \& Macdonald, D. D. (1998b). Recommended uses of empirically derived, sediment quality guidelines for marine and estuarine ecosystems. Human and Ecological Risk Assessment: An International Journal, 4, 1019-1039.

Ma, X. L., et al. (2016). Assessment of heavy metals contamination in sediments from three adjacent regions of the Yellow River using metal chemical fractions and multivariate analysis techniques. Chemosphere, 144, 264-272. https://doi. org/10.1016/j.chemosphere.2015.08.026.

MacDonald, D. D., Ingersoll, C. G., \& Berger, T. A. (2000). Development and evaluation of consensus-based sediment quality guidelines for freshwater ecosystems. Archives of Environmental Contamination and Toxicology, 39, 20-31. https://doi.org/10.1007/s002440010075.

Marrugo-Negrete, J., Pinedo-Hernández, J., \& Díez, S. (2017). Assessment of heavy metal pollution, spatial distribution and origin in agricultural soils along the Sinú River Basin, Colombia. Environmental Research, 154, 380-388.

Micó, C., Recatalá, L., Peris, M., \& Sánchez, J. (2006). Assessing heavy metal sources in agricultural soils of an European Mediterranean area by multivariate analysis. Chemosphere, 65, 863-872. https://doi. org/10.1016/j.chemosphere.2006.03.016. 
Morton-Bermea, O., Gómez-Bernal, J. M., Armienta, M. A., Lozano, R., Hernández-Álvarez, E., Romero, F., \& CastroLarragoitia, J. (2014). Metal accumulation by plant species growing on a mine contaminated site in Mexico. Environmental Earth Sciences, 71, 5207-5213.

Muller, G. (1969). Index of geoaccumulation in sediments of the Rhine River. Geojournal, 2, 108-118.

Natali, C., \& Bianchini, G. (2018). Natural vs anthropogenic components in sediments from the Po River delta coastal lagoons (NE Italy). Environmental Science and Pollution Research International, 25, 2981-2991. https://doi. org/10.1007/s11356-017-0986-y.

Nemati, K., Bakar, N. K. A., Abas, M. R., \& Sobhanzadeh, E. (2011). Speciation of heavy metals by modified BCR sequential extraction procedure in different depths of sediments from Sungai Buloh, Selangor, Malaysia. Journal of Hazardous Materials, 192, 402-410. https://doi. org/10.1016/j.jhazmat.2011.05.039.

Obrist, D., Kirk, J. L., Zhang, L., Sunderland, E. M., Jiskra, M., \& Selin, N. E. (2018). A review of global environmental mercury processes in response to human and natural perturbations: Changes of emissions, climate, and land use. Ambio, 47, 116-140. https://doi.org/10.1007/s13280-017-1004-9.

Pan, K., \& Wang, W. X. (2012). Trace metal contamination in estuarine and coastal environments in China. Science of the Total Environment, 421, 3-16. https://doi.org/10.1016/j. scitotenv.2011.03.013.

Pandey, M., Tripathi, S., Pandey, A. K., \& Tripathi, B. D. (2014). Risk assessment of metal species in sediments of the river Ganga. Catena, 122, 140-149. https://doi.org/10.1016/j. catena.2014.06.012.

Rai, R., Agrawal, M., \& Agrawal, S. B. (2016). Impact of heavy metals on physiological processes of plants: with special reference to photosynthetic system (pp. 127-140). New Delhi: Springer India.

Rovira, J., Mari, M., Schuhmacher, M., Nadal, M., \& Domingo, J. L. (2011). Monitoring environmental pollutants in the vicinity of a cement plant: A temporal study. Archives of Environmental Contamination and Toxicology, 60, 372384. https://doi.org/10.1007/s00244-010-9628-9.

Ruzickova, S., Remeteiova, D., Mickova, V., \& Dirner, V. (2018). Sediment matrix characterization as a tool for evaluating the environmental impact of heavy metals in metal mining, smelting, and ore processing areas. Environmental Monitoring and Assessment, 190, 158. https://doi. org/10.1007/s10661-018-6551-4.

Shi, C. (2016). Average background values of 39 chemical elements in stream sediments of China. Earth Science, 14, 234 258 (in chinese).

Sierra, C., Ruiz-Barzola, O., Menendez, M., Demey, J. R., \& Vicente-Villardon, J. L. (2017). Geochemical interactions study in surface river sediments at an artisanal mining area by means of canonical (MANOVA)-Biplot. Journal of Geochemical Exploration, 175, 72-81. https://doi. org/10.1016/j.gexplo.2017.01.002.

Simpson, S. L., \& Batley, G. E. (2007). Predicting metal toxicity in sediments: a critique of current approaches. Integrated Environmental Assessment and Management, 3, 18-31. https://doi.org/10.1002/ieam.5630030103.

Strzebońska, M., Jarosz-Krzemińska, E., \& Adamiec, E. (2017). Assessing historical mining and smelting effects on heavy metal pollution of river systems over span of two decades. Water, Air, and Soil Pollution, 228, 141-152.

Suresh, G., Ramasamy, V., Meenakshisundaram, V., Venkatachalapathy, R., \& Ponnusamy, V. (2011). Influence of mineralogical and heavy metal composition on natural radionuclide concentrations in the river sediments. Applied Radiation and Isotopes, 69, 1466-1474. https://doi. org/10.1016/j.apradiso.2011.05.020.

Taiwo, A. M., \& Awomeso, J. A. (2017). Assessment of trace metal concentration and health risk of artisanal gold mining activities in Ijeshaland, Osun state Nigeria - Part 1. Journal of Geochemical Exploration, 177, 1-10. https://doi. org/10.1016/j.gexplo.2017.01.009.

Tessier, A., \& Campbell, P. G. C. (1987). Partitioning of trace metals in sediments: relationships with bioavailability. Hydrobiologia, 149(1), 43-52.

Turekian, K. K. (1961). Distribution of the elements in some major units of the earth's crust. Geological Society of America Bulletin, 72, 175-182.

USEPA. (1989). Risk assessment guidance for superfund, volume 1, human health evaluation manual (part A). ReportEPA/ 540/1-89/002. Washington, DC: US Environmental Protection Agency.

USEPA. (2004). Risk assessment guidance for superfund, volumel, human health evaluation manual (part E, supplemental guidance for dermal risk assessment). Report EPA/540/R/99/005. Washington, DC: US Environmental Protection Agency.

Vallejo Toro, P. P., Vasquez Bedoya, L. F., Dario Correa, I., et al. (2016). Impact of terrestrial mining and intensive agriculture in pollution of estuarine surface sediments: spatial distribution of trace metals in the Gulf of Uraba, Colombia. Marine Pollution Bulletin, 111, 311-320. https://doi.org/10.1016/j. marpolbul.2016.06.093.

Varol, M. (2011). Assessment of heavy metal contamination in sediments of the Tigris River (Turkey) using pollution indices and multivariate statistical techniques. Journal of Hazardous Materials, 195, 355-364. https://doi.org/10.1016/j. jhazmat.2011.08.051.

Vianello, G., et al. (2014). Critical evaluation of an intercalibration project focused on the definition of new multi-element soil reference materials (AMS-MO1 AND AMS-ML1) Eqa. International Journal of Environmental Quality, 15, 41-64.

Wang, XL., Sato, T., Xing, BS., Tao, S. (2005). Health risks of heavy metals to the general public in Tianjin, China via consumption of vegetables and fish. Science of The Total Environment, 350, 28-37.

Wang, Y. B., Liu, C. W., \& Wang, S. W. (2015). Characterization of heavy-metal-contaminated sediment by using unsupervised multivariate techniques and health risk assessment. Ecotoxicology and Environmental Safety, 113, 469-476. https://doi.org/10.1016/j.ecoenv.2014.12.036.

Xia, F., Qu, L., Wang, T., Luo, L., Chen, H., Dahlgren, R. A., Zhang, M., Mei, K., \& Huang, H. (2018). Distribution and source analysis of heavy metal pollutants in sediments of a rapid developing urban river system. Chemosphere, 207, 218-228. https://doi.org/10.1016/j.chemosphere.2018.05.090.

Zhang, H., Yu, J., \& Zhou, S. (2014). Spatial distribution of As, Cr, $\mathrm{Pb}, \mathrm{Cd}, \mathrm{Cu}$, and $\mathrm{Zn}$ in the water and sediment of a river impacted by gold mining. Mine Water and the Environment, 33, 206-216. 